\title{
A System for Characterizing Cellular and Molecular Events in Programmed Neuronal Cell Death
}

\author{
Randall N. Pittman, Songli Wang, Angela J. DiBenedetto, and Jason C. Mills \\ Department of Pharmacology, University of Pennsylvania School of Medicine, Philadelphia, Pennsylvania 19104
}

A model system has been established in which PC12 cells are converted to neuronal-like cells that undergo transcription-dependent cell death following removal of NGF. Nineteen sublines of PC12 cells were tested to establish parameters for making cells dependent on NGF for survival. In most sublines, a relatively small percentage of cells become dependent on NGF for survival, and following removal of NGF, most of the cells begin proliferating in serum-containing medium. In several sublines, however, a significant percentage of cells die following removal of NGF. One of these sublines, PC6-3, can be grown under conditions in which $90 \%$ of the cells undergo transcription-dependent cell death following removal of NGF in either serum-free or serum-containing medium. Fourteen hours after removing NGF, $50 \%$ of the cells are committed to die, while initial morphological signs of cell death as determined by time-lapse videomicroscopy occur 2-6 hr later and include loss of neurites followed by a 1-3 hr period of active membrane "blebbing" and protrusions. Cell death can be blocked by the RNA synthesis inhibitor actinomycin $D$, the protein synthesis inhibitor cycloheximide, $\mathrm{KCl}$, basic fibroblast growth factor, or dibutrylCAMP, but not by epidermal growth factor, leupeptin, or the endonuclease inhibitor aurintricarboxylic acid (ATA). Removal of NGF activates an endonuclease that causes nucleosomal laddering of the DNA; however, endonuclease activity does not appear to be required for cell death. In agreement with previous studies (Batistatou and Greene, 1991; Rukenstein et al., 1991) demonstrating that naive PC12 cells undergo transcription-independent cell death when shifted into serum-free medium in the absence of growth factors, all cell lines tested except for one die when cultured in RPMI medium lacking growth factors. DNA fragmentation is a prominent feature of transcription-independent cell death, and death can be blocked with NGF, ATA, and dibutryl-CAMP but not with actinomycin $\mathrm{D}$ or $\mathrm{KCl}$. The PC12 model system described here should be useful for identifying cell death genes and for characterizing cellular and molecular events in programmed neuronal cell death.

[Key words: apoptosis, programmed cell death, PC12 cells, differentiation, NGF, RNA synthesis, protein synthesis, transcription dependence]

\footnotetext{
Received Oct. 15, 1992; revised Feb. 23, 1993; accepted Mar. 3, 1993.

This work was supported by grants from the Research Foundation of the University of Pennsylvania, and the ALS Association. We thank Jennifer Phillips for helpful comments on the manuscript and Drs. Joseph and Jean Sanger for their advice and for the use of their Time-Base Corrector and Print-Maker.

Correspondence should be addressed to Randall N. Pittman, Department of Pharmacology 6084, University of Pennsylvania School of Medicine, Philadelphia, PA 19104.

Copyright (C) 1993 Society for Neuroscience $0270-6474 / 93 / 133669-12 \$ 05.00 / 0$
}

Cell death in the developing nervous system is extensive and appears to result from a cascade of molecular and cellular events that occur at a specific stage of differentiation (for review, see Clarke, 1990; Ellis et al., 1991; Oppenheim, 1991). In some systems it appears that growth factors such as NGF can block cell death (Martin et al., 1988), while in other systems it appears that cell death is part of a developmental program that is not altered by growth factors (Ellis and Horvitz, 1986). In the vertebrate nervous system approximately half the neurons generated in many neuronal populations die over a relatively short period of time, typically during the period when synapses are being formed between neurons and their targets (Oppenheim, 1991). The emerging view is that developing neurons compete for a limited amount of or limited access to target-derived trophic factors. Trophic factors appear to enhance survival not by supporting life, but rather by blocking an endogenous cell death program (Martin et al., 1988; Oppenheim et al., 1990; Scott and Davies, 1990). Neurons that die during development (and possibly latter in life during aging and in diseases such as Alzheimer's or amyotrophic lateral sclerosis) may do so because they are unable to obtain sufficient quantities of trophic factors to block the endogenous cell death program.

There is considerable interest in identifying neuronal cell death genes. At present, several genes have been identified that appear to be involved in neuronal cell death. In Caenorhabditis elegans, 14 genes have been characterized that are involved in various aspects of programmed cell death (Sulston, 1976; Sulston and Horvitz, 1976; Hedgecock et al., 1983; Ellis and Horvitz, 1986; Yuan and Horvitz, 1990; Ellis et al., 1991; Hengartner et al., 1992). Three of these, ced-3, ced-4, and ced-9, are particularly interesting. Mutations in ced-3 or ced- 4 genes prevent programmed cell death during development, which suggests that these genes play an active role in determining which cells die. The ced- 9 gene product inhibits the function of ced- 3 and ced- 4 genes, and appears to be required to prevent normal cells from undergoing programmed cell death (Ellis et al., 1991; Hengartner et al., 1992). In Manduca sexta polyubiquitin is expressed in neurons and intersegmental muscles that are undergoing programmed cell death induced by a decline in circulating levels of 20-hydroxyecdysone (Schwartz et al., 1990a,b). The role of polyubiquitin in neuronal cell death, however, is not clear.

Little progress has been made in identifying genes involved in neuronal cell death in vertebrates; however, studies by Martin et al. (1988) and Scott and Davies (1990) using primary cultures of neurons and Oppenheim et al. (1990) using motoneurons in the chick lumbar spinal cord in vivo suggest that cell death of vertebrate neurons requires new RNA and protein synthesis. None of the genes or proteins involved in cell death of vertebrate neurons have been identified, and thus far the only protein that 
has been suggested to be involved in cell death of vertebrate neurons is an endonuclease that is activated when naive PC12 cells are shifted into serum-free medium in the absence of NGF or other growth factors (Batistatou and Greene, 1991; Ruckenstein et al., 1991). The cell death in this case, however, does not appear to require new RN $\Lambda$ or protein synthesis; therefore, the relationship between endonuclease activity and "programmed" neuronal cell death is not yet clear. Interestingly, nuclease activity appears to be involved in cell fragmentation during phagocytosis in late stages of programmed cell death in C. elegans (Sulston, 1976; Hevelone and Hartman, 1988), and in glucocorticoid-induced cell death of T-lymphocytes (Cohen and Duke, 1984, Wyllie et al., 1984, Shi et al., 1989); therefore, endonuclease activity may be a common feature of many types of cell death. Whether endonuclease activity is the cause or the result of cell death is an area of active research (Cohen and Duke, 1984; McConkey et al., 1989; Schwartzman and Cidlowski, 1991).

The number of genes and proteins involved in neuronal cell death in vertebrates is unknown. As genes are identified it will be increasingly important to understand their role in cell death and their relationship to other genes and proteins that are likely to make up a cascade of events resulting in cell death. In vitro model systems are needed for identifying genes and for understanding the various steps in a neuronal cell death cascade. A useful model system would consist of a homogeneous neuronal population that is easily available in large quantities and undergoes transcription-dependent cell death with a precise time course either as part of a developmental program or following trophic factor removal. At present, there are no systems that have all of these properties, although primary cultures of sympathetic neurons meet all the requirements except that large quantities of cells are not readily available. Primary cultures of rat sympathetic neurons require NGF for survival and, following removal of NGF, die 24-48 hr later (Martin et al., 1988). Cell death can be blocked by inhibiting RNA or protein synthesis, suggesting that cell death following removal of NGF requires new RNA and protein synthesis (i.e., a cell death program is activated upon removal of NGF).

The present study started with the hypothesis that if a neuronal cell line could be made dependent on a trophic factor such as NGF for survival, then it might serve as a good model system for identifying the cellular and molecular events responsible for cell death. By definition, cell lines are immortal; therefore, the initial step would be to establish conditions in which a neuroblastoma cell line would become dependent on a trophic factor for survival. Such a system would be useful not only for studying events in neuronal cell death but also for investigating molecular events involved in the irreversible commitment to a postmitotic phenotype. The pheochromocytoma cell line PC12 was chosen because of its well-characterized response to NGF (Greene and Tischler, 1976; for review, see Halegoua et al., 1991; Levi, 1991) and because of its similarity to sympathetic neurons, at present the best culture model of ncuronal cell death (Martin et al., 1988; Koike et al., 1989; Wallace and Johnson, 1989; Chang et al., 1990; Martin et al., 1990).

\section{Materlals and Methods}

Materials. Basic fibroblast growth factor (bFGF) was purchased from GIBCO-Bethesda Research Labs; fibronectin, from Boehringer Mannheim; laminin, from Collaborative Research; Protein A Sepharose, from Pharmacia; and dibutryl-cAMP (dbcAMP), aurintricarboxylic acid
(ATA), insulin, selenium, transferrin, progesterone, putrescine, polylysine, actinomycin D, cycloheximide, leupeptin, and 3,(4,5-dimethylthiazol-2-yl)2,5-diphenyl-tetrazolium bromide (MTT), from Sigma. Culture media were purchased from JRH Scientific (high-glucose DMEM, RPMI, and Ham's F12), GIBCO [minimum essential medium (MEM) and Ham's F12], or Sigma (L15). Horse and fetal calf serum were obtained from HyClone. NGF and epidermal growth factor (EGF) were prepared from male mouse saliva according to the method of Burton et al. (1978), or were purchased from UBI or Collaborative Research. Type I collagen was prepared from rat tails or purchased as bovine skin collagen from Sigma.

\section{Cell culture}

Nineteen sublines of $\mathrm{PC} 12$ cells were used in these studies. Three of these lines were isolated in 1986 and are designated PC2 (cells grow in small aggregates and have a rapid and robust response to NGF), PC4 (cells grow in amorphous large aggregates and exhibit weak morphological response to NGF; neurites grow within aggregates rather than on substrates), and PC6 (cells grow as single isolated cells, and have a slow but good morphological response to NGF). The other 16 lines were isolated by subcloning the PC6 parent line, and are designated PC6-1 through PC6-16.

PC1 2 cells were typically maintained in RPMI medium in $10 \%$ horse serum and $5 \%$ fetal calf serum and grown on tissue culture plastic (Corning). When cells were treated with NGF or used in experiments, they were grown on a matrix (generally type I collagen from rat tail or bovine skin). A large number of different growth conditions and substrates were tested in these studies; information on some of these different conditions are given in Results. The protocol presently bcing uscd to convert PC12 cells to a dependence on NGF for survival is as follows: the PC6-3 subline of PC12 cells are grown on type I collagen in RPMI medium containing $5 \%$ fetal calf serum and $10 \%$ horse serum for $7-10$ $\mathrm{d}$ in the presence of $100 \mathrm{ng} / \mathrm{ml} 2.5 \mathrm{~S}$ NGF with fresh medium being added every $2 \mathrm{~d}$. On day 7 or 10 the cells are removed from the dishes with Hank's balanced salt solution and trituration and replated onto dishes containing type I collagen in Dulbecco's modified Eagle's medium (DMEM)/F12 (1:1) serum-containing medium $(5 \%$ or $10 \%$ fetal calf serum) containing $100 \mathrm{ng} / \mathrm{ml} 2.5 \mathrm{~S} \mathrm{NGF}$, or serum-free medium (DMEM/ F12) containing insulin $(5 \mu \mathrm{g} / \mathrm{ml})$, transferrin $(10 \mu \mathrm{g} / \mathrm{ml})$, selenium $(30$ $\mu \mathrm{M})$, progesterone $(20 \mathrm{nM})$, putrescine $(100 \mu \mathrm{M})$, BSA $(100 \mu \mathrm{g} / \mathrm{ml})$, and 2.5S NGF $(100 \mathrm{ng} / \mathrm{ml})$. After an additional $7 \mathrm{~d}$, NGF is removed from cultures by adding medium lacking NGF (serum-free or serum-containing depending on the culturc conditions during the last 7 d) and containing $60 \mu \mathrm{g} / \mathrm{ml}$ anti-NGF IgG. Because NGF is a "sticky" molecule, the addition of antibodies provides a more precise time point for removal of the biological effects of NGF. The antibodies only "tighten up" the time course of cell death (without antibodies cells die between 24 and $96 \mathrm{hr}$ following removal of NGF; see Fig. 1; see also Martin et al., 1988)

\section{Assays for cell survival}

Lactate dehydrogenase. Release of the cytoplasmic enzyme lactate dehydrogenase $(\mathrm{LDH})$ was used as a measure of cell viability for some cultures grown in serum-free medium (serum contains LDH, which interferes with the assay). LDH activity was determined using a colorimetric assay (LDH diagnostic kit, Sigma) based on the conversion of pyruvic acid to lactic acid by LDH in the presence of NADH (Cabaud and Wroblewski, 1958). The assay was performed according to the manufacture's protocol. Total cellular LDH was determined by freezing and thawing cells two times.

MTT. A modification (Hansen et al., 1989) of the original procedure (Mosmann, 1983) using the tetrazolium salt MTT [3,(4,5-dimethylthiazol-2-yl)2,5-diphenyl-tetrazolium bromide] to measure mitochondrial function was used. In short, MTT $(1 \mathrm{mg} / \mathrm{ml}$ final concentration) was added to cultures of PC12 cells growing in serum-free or serumcontaining medium in 24-well dishes (10,000-30,000 cells/well) and incubated at $37^{\circ} \mathrm{C}$ for $1 \mathrm{hr}$. The assay was stopped by lysing cells with $20 \% \mathrm{SDS}$ in $50 \% \mathrm{~N}, \mathrm{~N}$-dimethyl formamide, $\mathrm{pH} 4.7$. This was then incubated overnight at $37^{\circ} \mathrm{C}$, transferred to a microtiter plate, and quantitated using an ELISA plate reader at $570 \mathrm{~nm}$. The assay was linear between 1000 and 40,000 cells and 45 and 150 min reaction time and was very reproducible between experiments.

Cell counts. Cells grown in 24-well culture dishes were counted at $200 \times$ magnification. Cell counts for each experimental condition consisted of five fields/well (center and 12, 3, 6, and 9 o'clock) and two or 


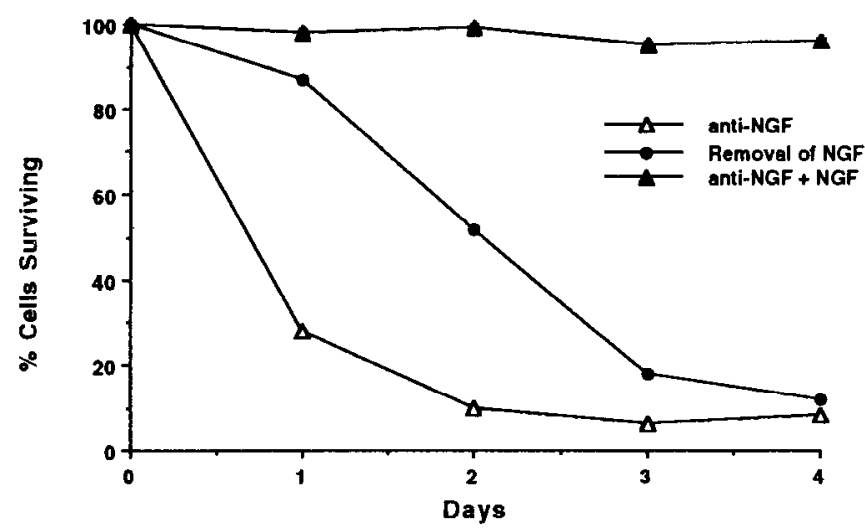

Figure 1. Cell death following removal of NGF in the absence (solid circle) or presence (open triangles) of antibodies directed against NGF. Data represent the means of cell counts (relative to the number of cells present in controls at the start of the experiment) of 10 fields for two cultures in two different platings. In the anti-NGF + NGF group (solid triangles), NGF was removed and $60 \mu \mathrm{g} / \mathrm{ml}$ anti-NGF added, followed $4 \mathrm{hr}$ later by the addition of $400 \mathrm{ng} / \mathrm{ml} \mathrm{NGF}$.

three wells/experiment. Therefore, $10-15$ fields containing $10-75$ cells each constituted $N=1$. Living cells were determined by phase-contrast characteristics of a smooth phase-bright cell body with clear cytoplasm. Strong correlations were obtained when comparing cell survival obtained from cell counts with survival based on the lactate dehydrogenase assay $(r=0.97)$ or MTT assay $(r=0.94)$.

\section{DNA laddering}

Soluble DNA was prepared from PC12 cells by the method of Davis et al. (1980). Approximately $5 \times 10^{6}$ cells were solubilized at $60^{\circ} \mathrm{C}$ for 2 $\mathrm{hr}$ in isotonic saline containing $0.1 \mathrm{M}$ EDTA, $1 \% \mathrm{SDS}, 100 \mu \mathrm{g} / \mathrm{ml}$ Proteinase $\mathrm{K}$, and $0.2 \mathrm{M}$ Tris, $\mathrm{pH} 8.5$, followed by precipitation of chromosomal DNA with $5 \mathrm{~m}$ potassium acetate and centrifugation for 15 min at $15,000 \times g$. Soluble DNA was precipitated from the supernatant with ice-cold ethanol and resuspended in $10 \mathrm{~mm}$ Tris/1 mM EDTA, $\mathrm{pH}$ 8.0, and the concentration of DNA was determined by UV absorbance at $260 \mathrm{~nm}$. Equal amounts of DNA were run in each lane of a $2 \%$ agarose gel.

\section{Time-lapse videomicroscopy}

Cells were cultured on collagen-coated glass coverslips attached to the bottom of $35 \mathrm{~mm}$ dishes in which a $1 \mathrm{~cm}$ hole had been drilled (MatTek Corp., Ashland, MA). Cultures were grown on the stage of a Nikon Diaphot microscope under $5 \% \mathrm{CO}_{2}$ by passing a mixture of $5 \% \mathrm{CO}_{2}$, $95 \%$ air through a port on the side of a specially designed culture chamber and maintained at $37^{\circ} \mathrm{C}$ by having the entire apparatus in a temperature-controlled warm room. Videomicroscopy was performed using a Panasonic videocamera with newvicon tube and Panasonic AG-6050 time-lapse video recorder. Images were enhanced using an Image 1/AT digital image processing system (Ivins and Pittman, 1989; Ivins et al., 1991).

\section{Antisera}

Antisera against NGF were prepared by injecting New Zealand White rabbits with $200 \mu \mathrm{g}$ of $2.5 \mathrm{~S}$ NGF in Freund's complete adjuvant, followed by two boosts 6 weeks apart with $100 \mu \mathrm{g}$ of $2.5 \mathrm{~S}$ NGF in Freund's incomplete adjuvant. Serum was collected from the marginal ear vein every 4 weeks and an IgG fraction prepared using Protein A Sepharose.

\section{Results}

\section{Characterizing sublines and culture conditions}

Initial studies indicated that $10-20 \%$ of two sublines, PC2 and PC6, became dependent on NGF for survival after $14 \mathrm{~d}$ of culturing on "native" substrates of laminin, fibronectin, type I collagen, and type IV collagen, but not on polylysine or tissue

\begin{tabular}{lrll}
\hline Table 1. & Cell death of PC6 sublines following removal of NGF \\
Subline & \% Survival & $\begin{array}{l}\text { Protection with } \\
\text { actinomycin D }\end{array}$ & $\begin{array}{l}\text { Background } \\
\text { cell death }\end{array}$ \\
\hline 1 & 23 & $* * *$ & Medium \\
2 & 91 & - & Low \\
3 & 4 & $* * *$ & Low \\
4 & 29 & $* *$ & Medium \\
5 & 44 & $* * *$ & Low \\
6 & 30 & $* *$ & Low \\
7 & 38 & $* *$ & Low \\
8 & 21 & $* *$ & High \\
9 & 7 & $*$ & High \\
10 & 19 & $* * *$ & High \\
11 & 24 & $* * *$ & Medium \\
12 & 32 & $* *$ & High \\
13 & 19 & $* *$ & High \\
14 & 34 & $* *$ & Low \\
15 & 8 & $* * *$ & Medium \\
16 & 37 & $*$ & High \\
\hline
\end{tabular}

The percentage survival was determined for 10 fields of cells in two cultures for each subline. Cell counts were made 36 hrs after removal of NGF. Background cell death was determined prior to removal of NGF and considered low if $0-3 \%$ of the cells/field were degenerating, medium if $4-7 \%$ of cells were degenerating, and high if $8-15 \%$ of the cells were degenerating. Addition of actinomycin $D$ at the time of NGF removal provided essentially complete protection $\left({ }^{* * *}\right)$, partial protection $\left(^{* *}\right)$, or very little protection $\left(^{*}\right)$ after $36 \mathrm{hr}$.

culture plastic. One subline, PC4, did not become dependent on NGF under any of the conditions tested. Several media (RPMI, F12, DMEM, L15, MEM, and DMEM/F12 mix) and growth factors (bFGF, EGF, and dbcAMP) were tested using PC2 and PC6 sublines cultured under a variety of experimental paradigms. From these experiments it was determined that for maximum dependence on NGF for survival, cells should be grown on type I collagen in a medium designed for PC1 2 cells consisting of RPMI medium containing 10\% horse serum, $5 \%$ fetal calf serum, and $100 \mathrm{ng} / \mathrm{ml} \mathrm{NGF}$ for the first $7-10 \mathrm{~d}$, and then subcultured onto type I collagen and grown in a medium designed to maintain primary culturcs of ncurons consisting of a $1: 1$ mixture of DMEM/F12 containing $5 \%$ or $10 \%$ fetal calf serum, or in serum-free DMEM/F12 containing N2 supplements (Bottenstein et al., 1980). The PC6 subline was chosen for further studies because of the lower spontaneous background cell death associated with these cells compared to the PC2 subline. Because spontaneous background cell death would likely complicate future biochemical and molecular studies, cell lines and conditions were chosen to minimize background death.

Under the paradigm described above, approximately $50 \%$ of the PC6 cells became dependent on NGF for survival. In an attempt to increase the percentage of cells dying following removal of NGF, PC6 cells were subcloned into 16 stable sublines and examined for their dependence on NGF for survival, for the ability of actinomycin D to block cell death, and for spontaneous background cell death (Table 1). One of these lines, PC6-3, had low spontaneous background cell death, greater than $90 \%$ of the cells became dependent on NGF for survival, and most of the cell death could be blocked with actinomycin $D$.

Transcription-dependent cell death in PC6-3 cells

Removal of NGF from cultures of PC6-3 cells results in about $90 \%$ of the cells dying over a period of 3-4 d (Fig. 1). Because 

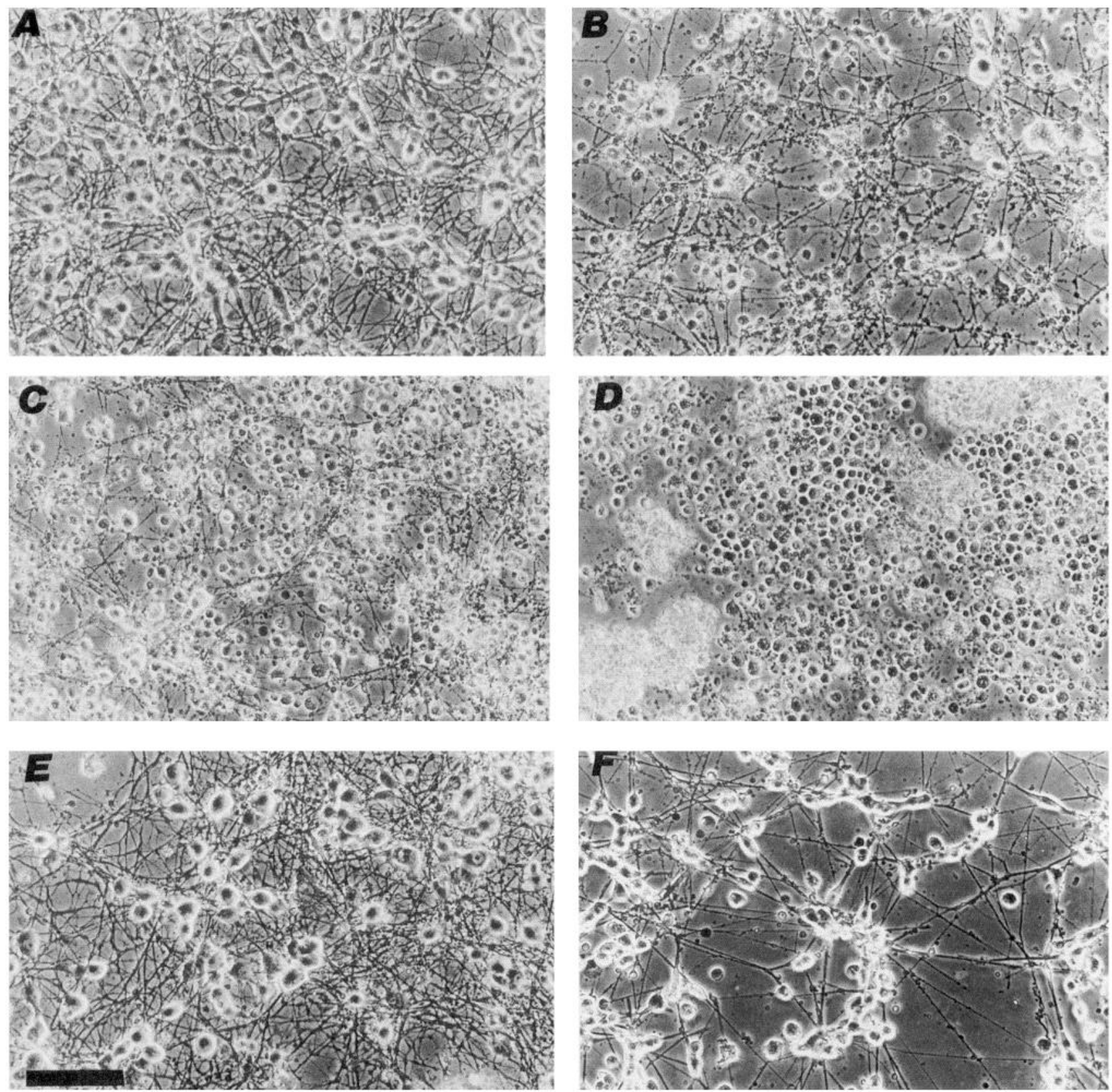

Figure 2. Cell death of PC6-3 cells following removal of NGF and protection with actinomycin D: control cells in the presence of NGF (A), or $20 \mathrm{hr}(B), 30 \mathrm{hr}(C)$, or $72 \mathrm{hr}(D)$ following removal of NGF. Actinomycin D $(2 \mu \mathrm{g} / \mathrm{ml})$ added at the time of NGF removal protects cells from death for $30 \mathrm{hr}(E)$ and $72 \mathrm{hr}(F)$. Cells were grown in serum-free medium during the last $7 \mathrm{~d}$ of culturing; similar data were obtained with cells grown in serum-containing medium. Scale bar, $100 \mu \mathrm{m}$.

NGF is a "sticky" molecule, the protracted period over which cells die may be due to the continued presence of NGF bound to serum proteins, cells, or the culture dish (see also Martin et al., 1988). When $60 \mu \mathrm{g} / \mathrm{ml}$ anti-NGF IgG is added to cultures, the time course of cell death is shortened considerably (Fig. 1). The possibility that antibodies bind to surface-bound NGF and are internalized and produce nonspecific effects was tested by exposing cells to antibodies for $4 \mathrm{hr}$ (sufficient time for internalization of surface-bound NGF and antibodies) followed by adding a fourfold excess of NGF to the cultures. No cell death occurs during the $4 \mathrm{~d}$ period when cells are treated with antibodies followed by excess NGF (Fig. 1). As an additional control to rule out nonspecific effects of antibodies, antibodies directed against tissue plasminogen activator (tPA; a soluble molecule present in the culture that binds to the surface of PC12 cells; Pittman et al., 1989) were added to cultures of differentiated PC1 2 cells. Antibodies against tPA did not alter the time course of cell death following removal of NGF(R. N. Pittman, S. Wang, A. DiBenedetto, and J. Mills, unpublished observations). In all subsequent experiments, anti-NGF IgG is included in medium when NGF-containing medium is removed.

After $14 \mathrm{~d}$ in the presence of NGF, PC6-3 cells appear very neuronal (Fig. 2A). Following removal of NGF, the first morphological signs of cell death at the light microscopic level occur after about $16 \mathrm{hr}$ and involve the thinning and "beading" of some of the neurites. By $20 \mathrm{hr}$ after removal of NGF, a number 

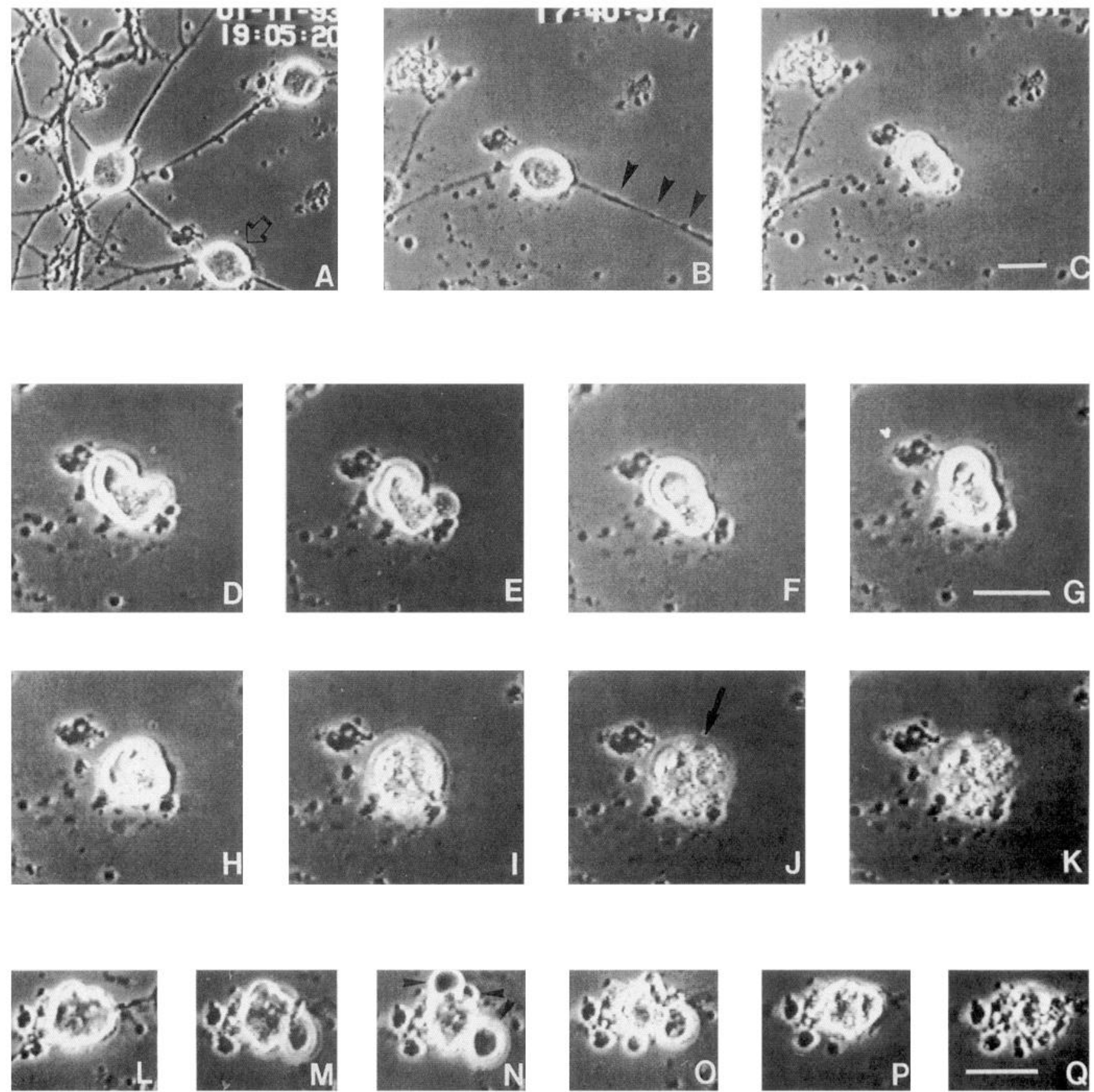

Figure 3. Morphological changes occurring after removing NGF. Continuous time-lapse videomicroscopy was performed on cell cultures following removal of NGF. The cell in the lower part of $A$ (open arrow) is depicted at various stages of cell death $(A-K)$. Thinning and "beading" of neurites (arrowheads, $B$ ) begins $26 \mathrm{hr}$ after removing NGF and neurites have essentially disappeared 35 min later $(C$; a very thin neurite $\sim 0.1 \mu \mathrm{m}$ in diameter is all that remains). Constant changes in the shape of the cell body occur over the next $2.5 \mathrm{hr}(C-G$, taken at $30 \mathrm{~min}$ intervals). This is followed by a period of 3-4 hr of little change in the shape of the cell body $(H)$. The cell body then swells slightly $(I)$ and appears to burst $(J$, taken $4 \mathrm{sec}$ after $I$; arrow points to rupture in plasma membrane), and finally cell debris is all that remains $(K$, taken 16 sec after $J)$. $L-Q$ depict a slightly different morphology associated with cell death in these cultures. $L$ is taken just before neurites degenerate; the cell body has already started to lose its typical smooth, rounded shape. Active protrusion and retraction of "apoptotic-like" bodies occurs following loss of neurites (arrowheads in $N$ point to some of these protrusions). $M$ and $N$ are taken 10 and $25 \mathrm{~min}$, respectively, after loss of neurites, and $O, 3 \mathrm{hr}$ after loss of neurites. After this period of active protrusions, the cell body becomes fairly quiescent for $2-3 \mathrm{hr}(P)$, and then swells slightly and ruptures, leaving behind cellular debris $(Q)$. Three different magnifications are present: $A-C(20 \mu \mathrm{m}$ bar in $C), D-K(20 \mu \mathrm{m}$ bar in $G)$, and $L-Q(20 \mu \mathrm{m}$ bar in $Q)$.

of neurites have been lost and some of the cell bodies are beginning to degenerate (Fig. $2 B$ ). By $24-30 \mathrm{hr}$, extensive loss of neurites occurs and cellular degeneration is obvious (Fig. $2 C$ ). Over the next $12 \mathrm{hr}$ most of the remaining cells die. The RNA synthesis inhibitor, actinomycin D, blocks the majority of the cell death when added to cultures at the time of NGF removal (Fig. 2E). Even $72 \mathrm{hr}$ after removal of NGF when most cells are dead and much of the cellular debris has detached from the substrate (Fig. 2D), actinomycin D still effectively blocks much of the cell death (Fig $2 F$ ). After 3.5-4 d of treatment, actino- 


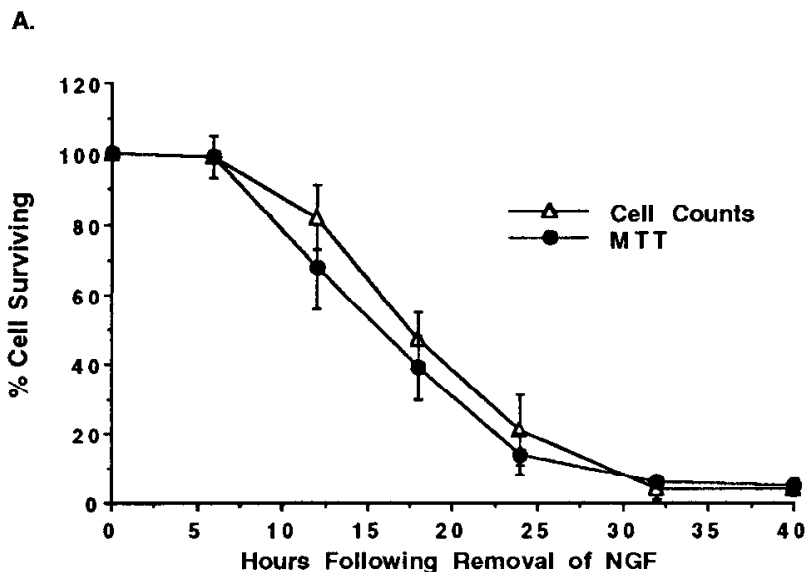

B.

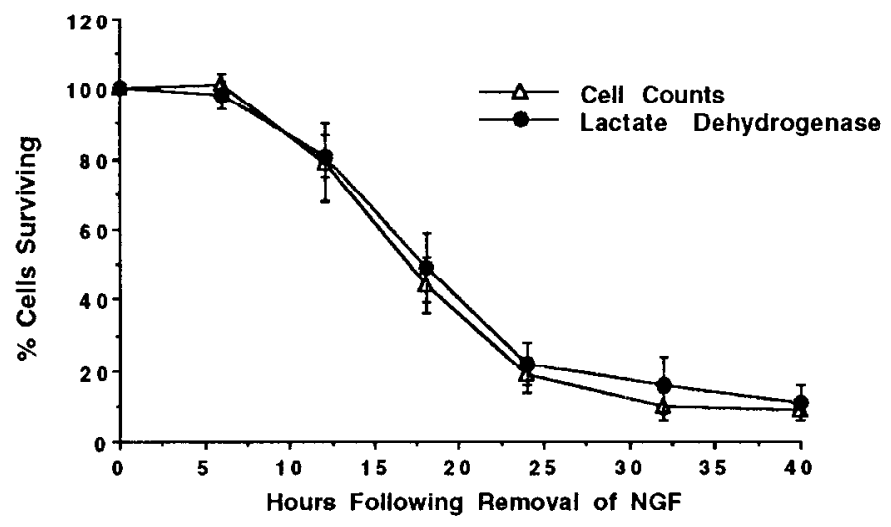

Figure 4. Comparison of different methods for determining cell survival. Data in $A$ were taken from cultures grown in serum-containing medium (similar data were obtained for MTT and cell counts in serumfree medium). Data in $B$ were taken from cultures grown in serum-free medium for the last $7 \mathrm{~d}$ of culturing (serum contains LDH; therefore, LDH activity has been determined only in cultures grown in serumfree medium). Data represent means $( \pm S D)$ of three different experiments performed in duplicate for cell counts (open triangles), MTT (solid circles in $A$ ), and LDH (solid circles in $B$ ). Correlations: cell counts versus MTT, $r=0.94$; cell counts versus $\mathrm{LDH}, r=0.97$; MTT versus $\mathrm{LDH}, r=0.92$.

mycin D itself is toxic and eventually kills all cells during the next $24 \mathrm{hr}$ in the presence or absence of NGF.

Time-lapse videomicroscopy was performed to examine in greater detail morphological changes occurring after removing NGF. Neurites of the cell indicated by the open arrow in Figure 3.4 begin "beading" (Fig. 3B, arrowheads) and thinning $26 \mathrm{hr}$ after removing NGF. About 30 min later, neurites have thinned to fine threads, and the cell body is beginning to alter its shape drastically (Fig. 3C). By $27 \mathrm{hr}$ after NGF removal, the cell has lost its neurites and is in the midst of convulsive expansions and contractions (Fig. $3 D-G$ taken at approximately $30 \mathrm{~min}$ intervals). After $2.5 \mathrm{hr}$ of these dramatic shape changes, the cell returns to a relative quiescent state for about $3.5 \mathrm{hr}$ (Fig. $3 \mathrm{H}$ is representative of this stage). Then suddenly, over a period of minutes, it begins to swell slightly (Fig. 3I) until the plasma membrane appears to lyse (Fig. $3 J$, arrow), and the cell ceases all activity and remains a collection of debris and membrane fragments (Fig. $3 K$ ). A slightly different form of death typical in these cultures is exemplified in Figure $3 L-Q$. The cell body as a whole seems more stable, but large membrane "blebs" reminiscent of apoptotic bodies seen in various cell types (Clarke,

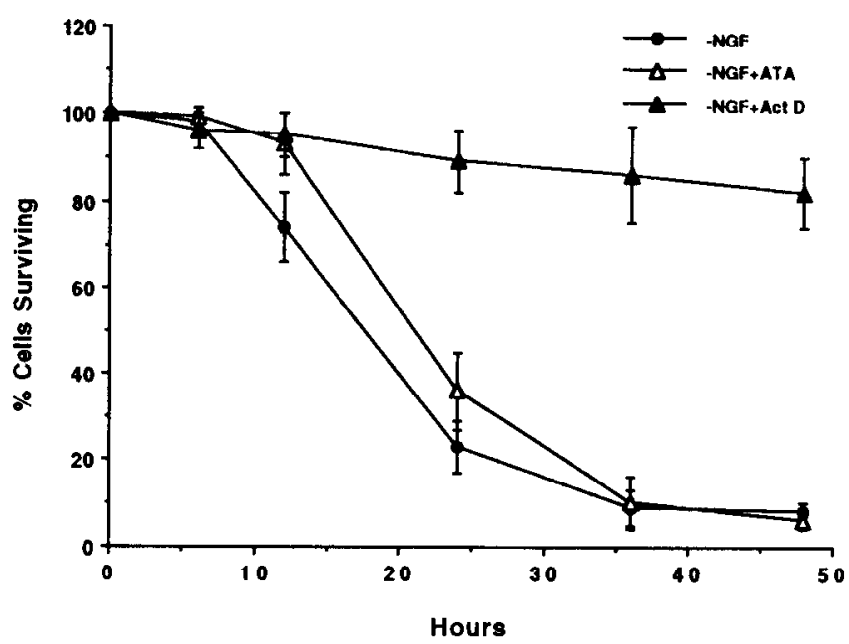

Figure 5. Effect of actinomycin D $(2 \mu \mathrm{g} / \mathrm{ml}$; solid triangles $)$ and ATA ( $30 \mu \mathrm{M}$; open triangles) on cell death following removal of NGF (solid circles reflect survival in the absence of additives). Data represent means $( \pm \mathrm{SD})$ of three different experiments performed in duplicate and expressed relative to the number of cells present at the start of the experiment. NGF was removed from all cultures at time 0 , and cell survival was determined using MTT.

1990) are quickly extended and retracted at multiple sites around the periphery of the cell body (Fig. $3 M-O$; arrowheads in Fig. $3 N$ ). After a period of $3 \mathrm{hr}$ of many such cycles of "bleb" extension and retraction, the cell exhibits the same morphological changes described above: a quiescent phase (Fig. $3 P$ ), a swelling (not shown), and finally fragmentation and cell debris (Fig. $3 Q$ ).

Three different assays have been used to quantitate cell viability (Fig. $4 A, B$ ). Similar cell survival data is obtained using cell counts, release of the cytoplasmic enzyme LDH, or the tetrazolium dye MTT, which provides a measure of mitochondrial function. Release of LDH is used to quantitate cell survival in serum-free cultures only because of its high background activity in serum-containing cultures. Strong correlations exist when comparing these measures of cell viability $(r=0.94$, cell counts vs MTT; $r=0.97$, cell counts vs LDH; $r=0.92$, MTT vs $\mathrm{LDH}$ ).

\section{Prevention of cell death following removal of NGF}

A requirement for new RNA synthesis has been suggested and/ or shown to be required for cell death in a number of systems (Tala, 1966; Lockshin, 1969; Horvitz et al., 1982; Cohen and Duke; 1984; Wyllie et al., 1984; Martin et al., 1988; Oppenheim et al., 1990), and a calcium-dependent endonuclease is activated in a variety of dying cells (Cohen and Duke, 1984; Wyllie et al., 1984; McConkey et al., 1989; Batistatou and Greene, 1991). Cell death of PC6-3 cells following removal of NGF is effectively blocked for at least $48 \mathrm{hr}$ in the presence of the RNA synthesis inhibitor actinomycin $\mathrm{D}$ but not in the presence of the endonuclease inhibitor ATA (Fig. 5). These observations are consistent with the idca that cell death in this system requires new RNA synthesis but does not require endonuclease activity. DNA "laddering" into multiples of 180-200 base pair nucleosomes as a result of endonuclease activity is a cardinal feature of apoptotic cell death and is suggested to be the reason for cells dying (McConkey et al., 1989). Although DNA laddering is present $14 \mathrm{hr}$ after removal of NGF from PC6-3 cells (Fig. 6, lane 4), it also occurs to some extent in cells treated with actinomycin $\mathrm{D}$ (Fig. 6, lane 5) that do not die during the first $48 \mathrm{hr}$ following 


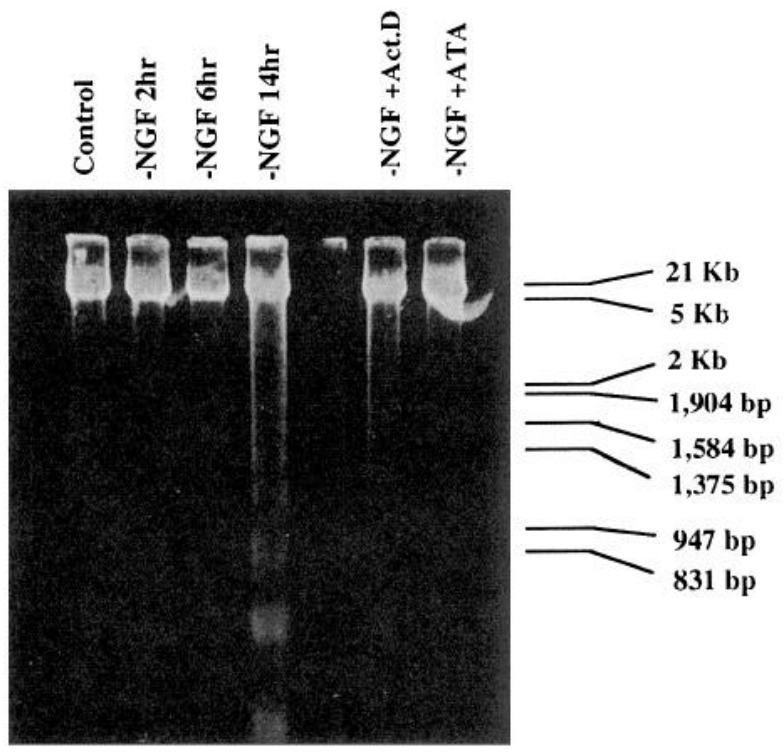

Figure 6. DNA laddering following removal of NGF. A small amount of background DNA laddering is present in control cultures (lane 1) and appears to be due to background cell death in these cultures. Following removal of NGF, no increase in DNA laddering occurs during the first $6 \mathrm{hr}$ (lanes 2, 3), but is obvious at $14 \mathrm{hr}$ (lane 4). Some DNA laddering occurs in the presence of actinomycin $\mathrm{D}$ (lane 5 ) but is blocked by ATA (lane 6$)$.

removal of NGF (see Fig. 5). In addition, DNA laddering is effectively blocked by ATA (Fig. 6, lane 6), which does not block cell death (see Fig. 5). Therefore, although DNA laddering occurs in differentiated PC6-3 cells following removal of NGF, it does not appear to be required for death of these cells.

Besides actinomycin D, other treatments that block cell death include $35 \mathrm{~mm} \mathrm{KCl}, 1 \mathrm{~mm}$ dbcAMP, $20 \mathrm{ng} / \mathrm{ml} \mathrm{bFGF}$, and 10 $\mu \mathrm{g} / \mathrm{ml}$ cycloheximide (Fig. 7). Agents that have no effect on cell survival include 30 or $100 \mu \mathrm{M}$ ATA, 10 or $100 \mathrm{ng} / \mathrm{ml} \mathrm{EGF}$, and $100 \mu \mathrm{g} / \mathrm{ml}$ leupeptin (Fig. 7). Although leupeptin has no effect on cell survival, cell death in the presence of leupeptin differs from other treatments. Typically, the first morphological changes that occur following removal of NGF are the beading of neurites followed by fragmentation of neurites and death of the cell body. Many cells treated with leupeptin maintain morphologically healthy neurites even though the cell body is compacted and fragmented (most obvious 18-30 hr after removal of NGF; data not shown). By $48 \mathrm{hr}$ after removal of NGF, neurites are fragmented even in the presence of leupeptin, but this typically occurs following demise of the cell body and not prior to changes in the cell body as is more typical of controls and other treatments. The late degeneration of neurites in the presence of leupeptin is probably due to the ability of leupeptin to inhibit calcium-dependent cysteine proteinases (such as the calpains) that are involved in degradation of neurofilaments and other cytoskeletal proteins (Melloni and Pontremoli, 1989).

To define more clearly the time after removal of NGF that cells are irreversibly committed to die, NGF was removed from cells and actinomycin D or NGF added to cultures at $6 \mathrm{hr}$ intervals (Fig. 8) and then the number of living cells was determined after $48 \mathrm{hr}$. Cells do not exhibit morphological signs of cell death at the light microscopic level $12 \mathrm{hr}$ after removal of NGF; however, $40-50 \%$ of the cells are already committed to die at this point. By $18-24 \mathrm{hr}$, essentially all cells that will

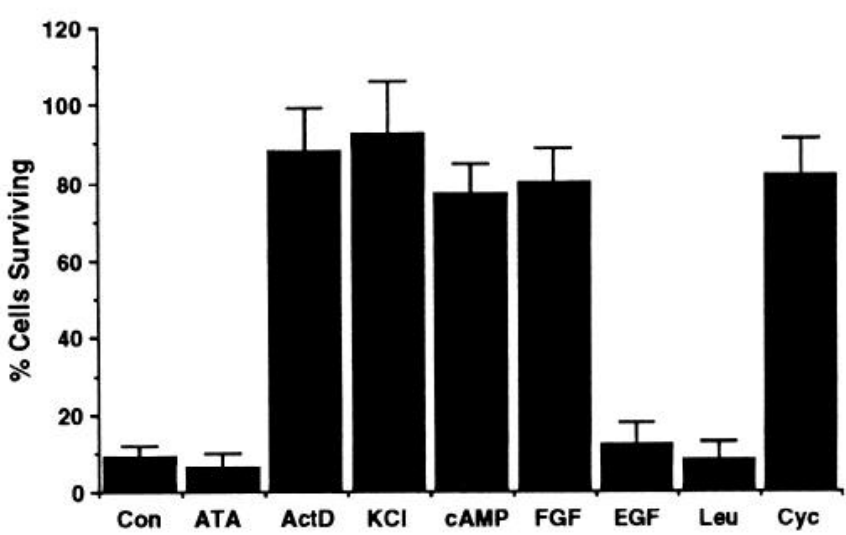

Figure 7. Ability of agents to block cell death following removal of NGF. Data were taken $36 \mathrm{hr}$ after removal of NGF and represent means $( \pm S D)$ relative to survival in the presence of NGF of three different experiments performed in duplicate. Agents were added at time 0:30 $\mu \mathrm{M}$ ATA, $2 \mu \mathrm{g} / \mathrm{ml}$ actinomycin D, $35 \mathrm{~mm} \mathrm{KCl}, 1 \mathrm{~mm}$ dbcAMP, $20 \mathrm{ng} /$ $\mathrm{ml} \mathrm{bFGF,} 100 \mathrm{ng} / \mathrm{ml} \mathrm{EGF}, 100 \mu \mathrm{g} / \mathrm{ml}$ leupeptin (leu), and $10 \mu \mathrm{g} / \mathrm{ml}$ cycloheximide $(c y c)$.

die within the first $48 \mathrm{hr}$ after removal of NGF are committed to die (Fig. 8). These data suggest that 12-14 hr after removal of NGF, half the cells have generated sufficient "killer" mRNA and/or protein to die over the next several hours. The difference in survival between actinomycin D and NGF at early time points is due to a small amount (about 10\%) of transcriptionindependent cell death. Addition of NGF at early times can block transcription-independent death, but addition of actinomycin D cannot. Therefore, no difference was observed for the time of commitment to cell death as defined by NGF or actinomycin D (but see Edwards et al., 1991).

\section{Transcription-independent cell death of PC6 cells}

PC12 cells undergo transcription-independent cell death when shifted into serum-free medium lacking growth factors (Batistatou and Greene, 1991; Ruckenstein, 1991). To gain a better understanding of the similarities between the transcription-dependent and -independent cell death of PC12 cells, 16 sublines

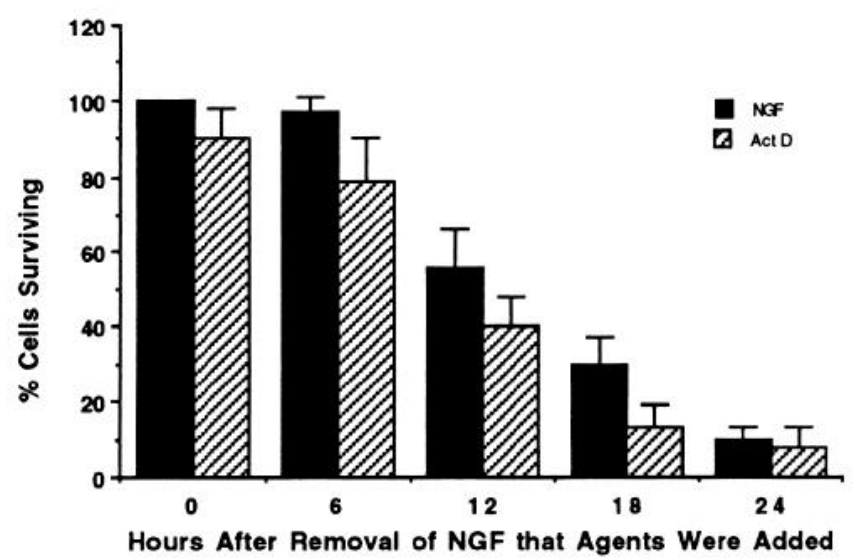

Figure 8. Time of commitment to cell death following removal of NGF. Data are expressed relative to the number of cells in the presence of NGF at time 0 and represent averages $( \pm$ SD) of three different experiments performed in duplicate. NGF $(100 \mathrm{ng} / \mathrm{ml}$, solid bars $)$ or actinomycin D $(2 \mu \mathrm{g} / \mathrm{ml}$, hatched bars $)$ were added $0,6,12,18$, or $24 \mathrm{hr}$ after removal of NGF from cultures. Cell survival was determined 48 hr after removal of NGF using MTT. 


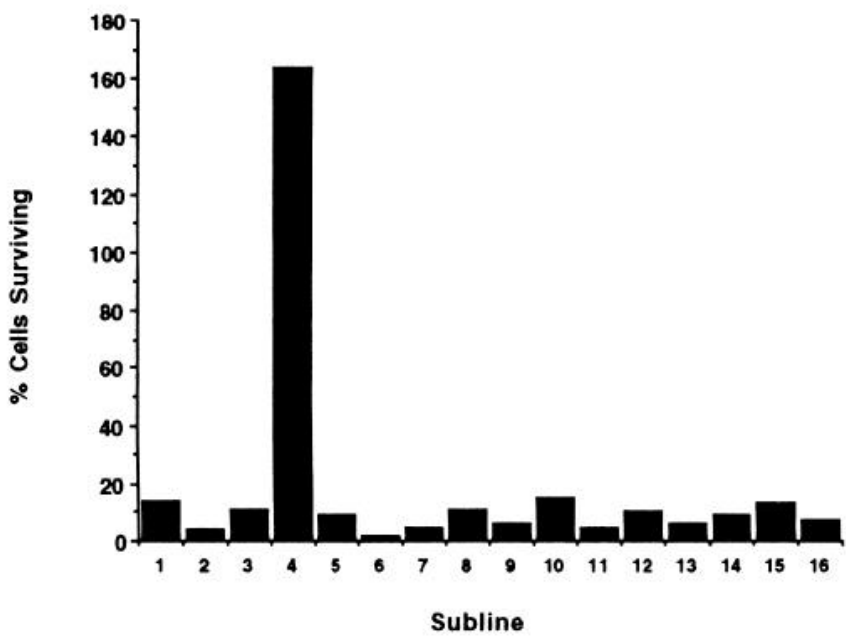

Figure 9. Survival of different sublines of PC6 cells in medium lacking serum and growth factors. Cells were shifted into RPMI medium lacking any additives and cell counts made $5 \mathrm{~d}$ later. Data represent the average of two experiments performed in triplicate and are expressed as a percentage of the cells plated.

of PC6 cells (see Table 1) were tested in the transcription-independent cell death paradigm established by Ruckenstein et al. (1991). The majority of cells in most sublines die during the first $4 \mathrm{~d}$ in serum-free RPMI medium (Figs. 9, 10A,B). Cells of the PC6-4 subline, however, show very little death in this paradigm (Figs. 9, 10D). This is markedly different from the extensive cell death of PC6-4 cells that occurs following removal of NGF in the transcription-dependent paradigm described above (Table 1).

Transcription-independent cell death of $\mathrm{PC} 12$ cells can be blocked by the endonuclease inhibitor ATA (Batistatou and
Greene, 1991). PC6-3, PC6-4, PC6-11, and PC6-15 cells were chosen to characterize further the role of endonucleases in transcription-independent cell death. ATA blocks death of PC6-3 cells (Fig. 10C) as well as PC6-11 and PC6-15 cells (data not shown). PC6-3, PC6-11, and PC6-15 sublines show a similar concentration-dependent rescue by ATA, with $30 \mu \mathrm{M}$ being the most effective concentration for blocking cell death (Pittman, Wang, DiBenedetto, and Mills, unpublished observations). ATA maintains all three sublines for at least $8 \mathrm{~d}$ in serum-free RPMI (data for PC6-3, Fig. 11A). The number of PC6-4 cells is greater in the presence of ATA (Fig. 11B), suggesting that some cell death may occur in PC6-4 cells that is blocked by ATA. A small number of degenerating cells are seen in cultures of PC6-4 cells (Fig. 10D), which is consistent with a greatly reduced amount of cell death in these cells rather than a total absence of transcription-independent cell death. This is also supported by the very low but detectable level of DNA "laddering" in PC6-4 cells that is blocked with ATA (Fig. 12, lanes 1-4). DNA laddering occurs in PC6-3, PC6-11, and PC6-15 cells as early as 6-10 hr after cells are shifted into serum-free medium, and extensive laddering is present after 18-24 hr in serum-free medium (Fig. 12 , lanes 6,8$)$. Essentially all of the DNA laddering is blocked with $30 \mu$ M ATA (Fig. 12, lanes 5, 7).

Whereas ATA blocks cell death of PC6 cells shifted into serum-free medium, actinomycin D has little or no effect on the rate of cell death (Fig. 13). The inability of actinomycin D to block cell death does not appear to be due to direct toxicity (at least during the first $2 \mathrm{~d}$ ), since actinomycin $\mathrm{D}$ does not significantly reduce the survival enhancing effects of NGF until days 3-5 (Fig. 13). In addition to ATA and NGF, dbcAMP blocks cell death of PC6 cells shifted into serum-free medium (Fig. 14). $\mathrm{KCl}$ does not block the death of cells, and significantly reduces survival of PC6-4 cells compared to controls, NGF-treated cells, or dbcAMP-treated cells (Fig. 14).
Figure 10. Death of cells in medium lacking serum and growth factors and protection by ATA. $A$ and $B$, PC6-11 $(A)$ and PC6-3 $(B)$ cells in serum-free medium lacking growth factors for $4 \mathrm{~d}$. Note that most cells have degenerated. $C$ and $D$, PC6-3 cells after $8 \mathrm{~d}$ in medium containing $30 \mu \mathrm{M}$ ATA $(C)$, and PC6 -4 cells after $8 \mathrm{~d}$ in medium lacking any additives $(D)$. Few if any PC6-3 cells die in the presence of ATA, and very few cells in the PC6-4 subline die. Arrows in $D$ point to a small number of degenerating cells in the PC6-4 subline. Scale bar: $100 \mu \mathrm{m}$ for $A, B$, and $D$; $200 \mu \mathrm{m}$ for $C$.
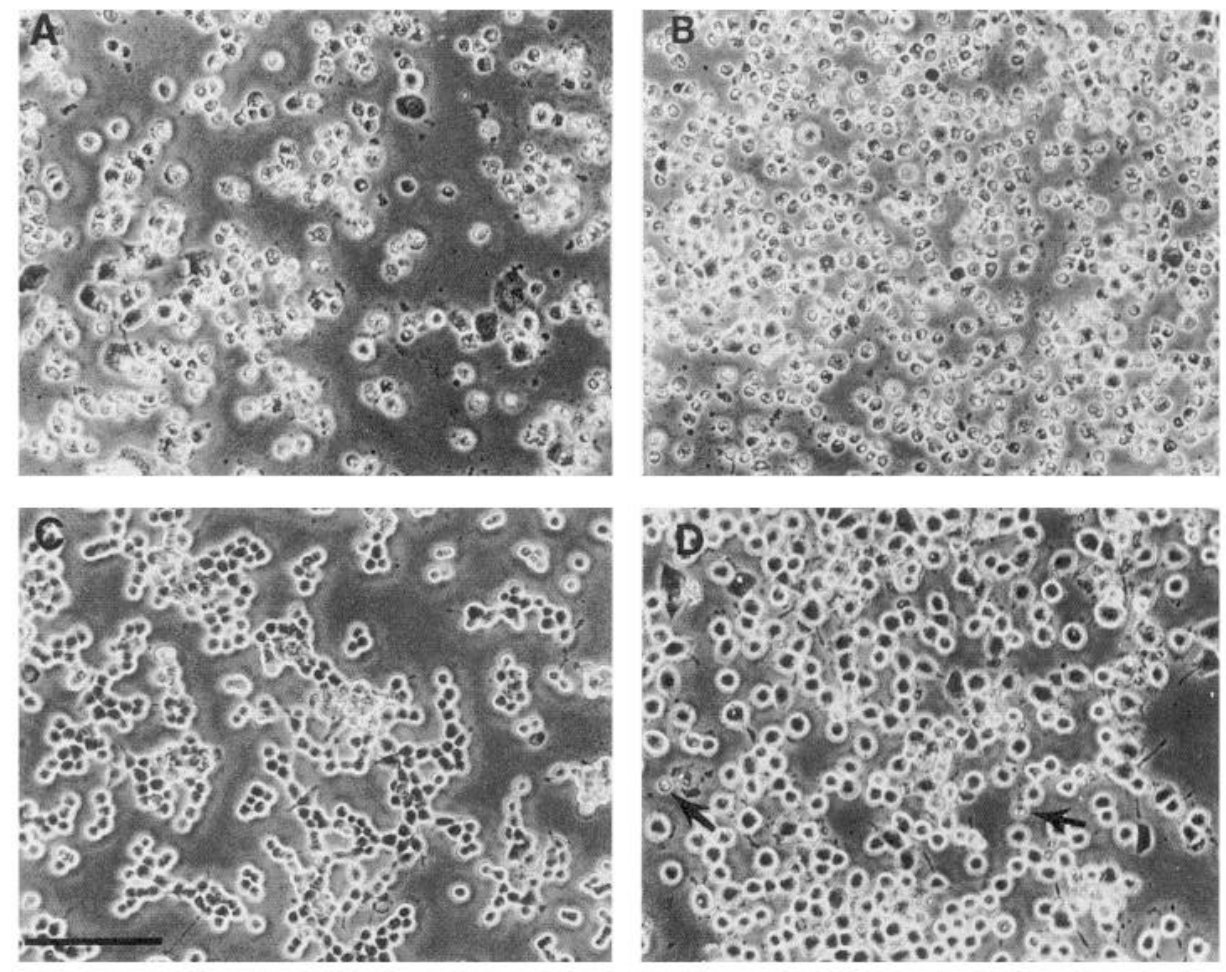
A.

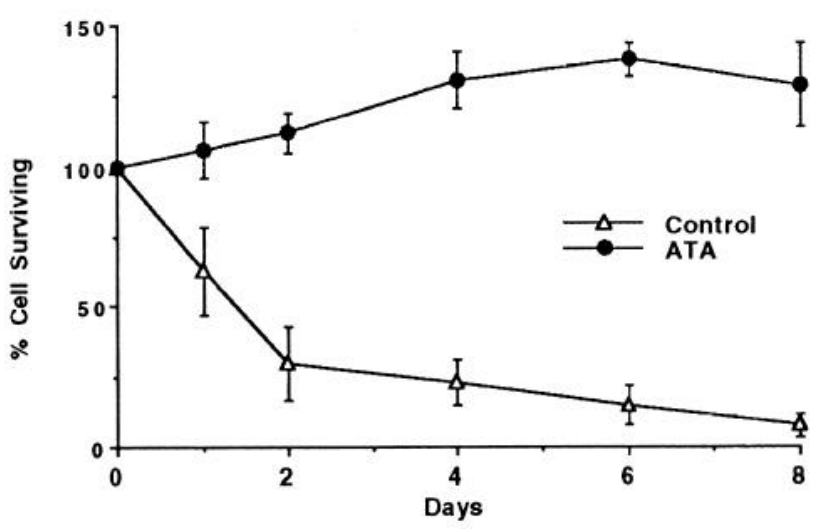

B.

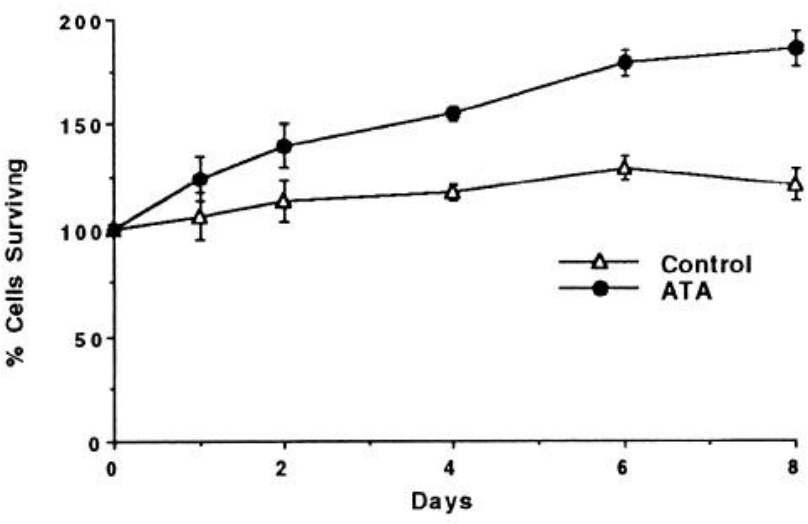

Figure 11. Time course of survival of PC6-3 $(A)$ and PC6-4 cells $(B)$ in the absence (open triangles) or presence (solid circles) of ATA in serum-free medium lacking growth factors. Data represent averages $( \pm S D)$ of three different experiments performed in duplicate and are expressed as a percentage of the number of cells plated. Cell survival was determined using cell counts (two experiments) or MTT (one experiment). Data similar to that for PC6-3 cells were obtained with PC611 and PC6-15 cells.

\section{Discussion}

Until recently, cell death was viewed as a passive process. The general view was that cells died because they ran out of molecules necessary for survival or that a series of molecular "errors" accumulated until basic cellular processes were compromised. It now appears that at least in a number of situations during development and possibly later in life, cells die because an endogenous "death program" is activated (Cohen and Duke, 1984; Ellis and Horvitz, 1986; Martin et al., 1988; Oppenheim et al., 1990; Schwartz et al., 1990). In parallel with this view of cells having a death program is the emerging view that one important function of growth factors may be to inhibit the activation of endogenous cell death genes (Duke and Cohen, 1986; Martin et al., 1988; McConkey et al., 1990; Oppenheim et al., 1990; Williams et al., 1990). A fundamental knowledge of genes that control cell death is important for understanding developmental events and could also provide potentially important information about pathophysiologies associated with the normal aging process and diseases.

An understanding of the mechanisms responsible for neuronal cell death require model systems for identifying molecules and pathways in the process. Useful properties of a model system

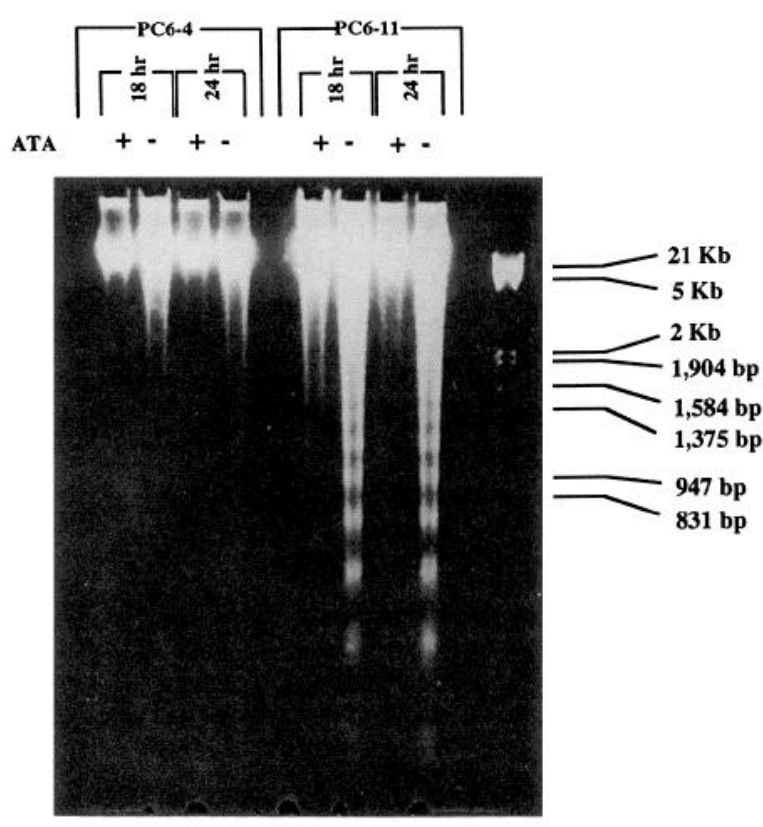

Figure 12. DNA laddering of PC6-4 and PC6-11 cells in the absence and presence of ATA. A large amount of DNA laddering is present in PC6-11 cells 18 and $24 \mathrm{hr}$ after shifting cells into serum-free medium lacking growth factors. ATA is able to block most of the DNA laddering. A small but detectable amount of DNA laddering occurs in PC6-4 cells, and this is blocked by ATA. Similar DNA laddering patterns to that seen for PC6-11 cells are seen with PC6-3 and PC6-15 cells in the absence and presence of ATA (not shown).

would include the following: (1) a homogeneous neuronal population, (2) cells available in large quantities, (3) death occurring with a reproducible time course either as part of a developmental program or following trophic factor removal, and (4) events identified in vitro accurately reflecting events in vivo. Our starting hypothesis was that if a neuronal cell line could be made to be dependent on a trophic factor such as NGF for survival, then it may serve as a good model system for identifying cellular and molecular events in cell death. The PC1 2 cell system described

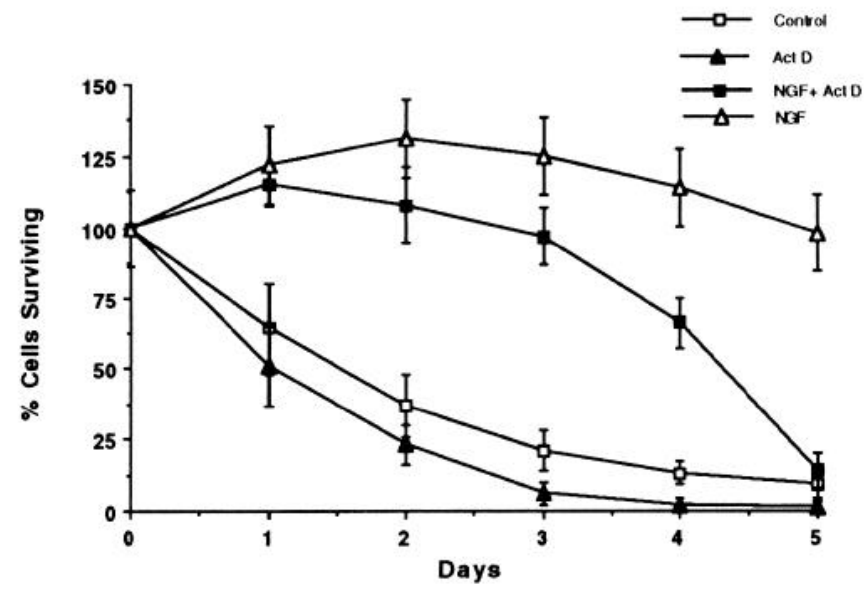

Figure 13. Time course of survival of PC6-3 cells in the absence of agents (open squares) or in the presence of actinomycin D (solid triangles), or NGF (open triangles), or actinomycin D + NGF (solid squares) in serum-free medium lacking growth factors. Data represent means $( \pm \mathrm{SD})$ of three different experiments performed in duplicate. Cell survival was determined using MTT and is expressed as a percentage of cells plated. 


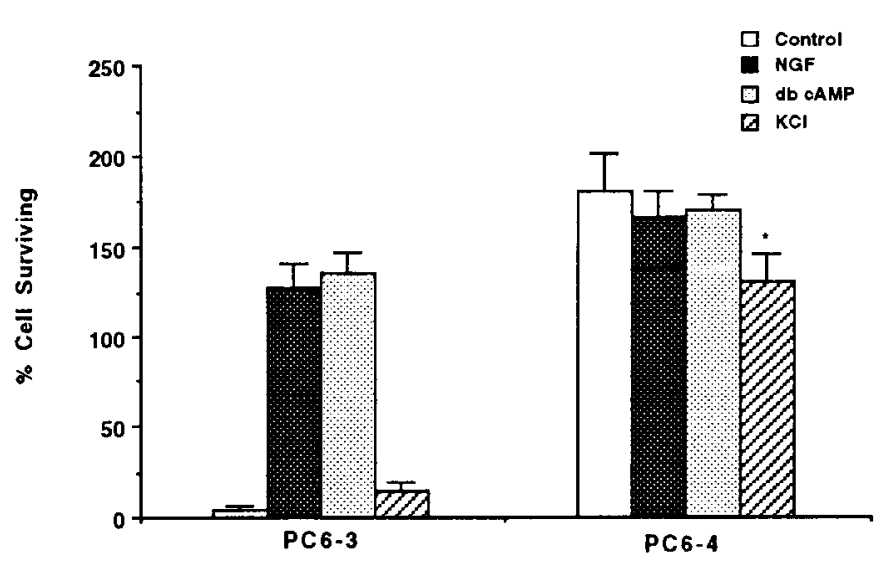

Figure 14. Survival of cells in the presence of NGF, dbcAMP, or $\mathrm{KCl}$. Cell counts were made after $5 \mathrm{~d}$ in serum-free medium and represent means $( \pm S D)$ of three different experiments performed in duplicate. Data are expressed as a percentage of cells plated. Survival of PC6-4 cells was significantly decreased in the presence of $\mathrm{KCl}$ compared to the other three groups $\left(^{*}, p<0.05\right)$. Data similar to that obtained with PC6-3 were obtained with PC6-11 and PC6-15 cells.

in the present study has the advantages that it is more easily manipulated than in vivo systems and consists of a homogeneous population of cells available in large quantities. However, by definition cell lines are immortal, which raises an important issue concerning the ability of a cell line to reflect accurately the properties of neurons in vitro or in vivo. Although there is no way a priori to know if the PC12 system described here accurately reflects events in vivo, the data obtained with this system are similar to data obtained with sympathetic neurons in vitro (Martin et al., 1988) and with chick spinal motoneurons in vivo (Oppenheim et al., 1990). We have initiated studies to characterize genes upregulated in PC6-3 cells committed to die following removal of NGF. Information on whether these genes are also upregulated in primary cultures of neurons deprived of trophic support or in developing populations of neurons undergoing cell death will be important for determining whether or not PC6-3 cells are a useful model system for studying differentiated properties of neurons. A similar model system consisting of PC12 cells that undergo transcription-dependent cell death has been recently described by Koike (1992).

Experiments in the present study demonstrate that PC12 cells can be cultured under conditions that result in their becoming dependent on NGF for survival and following removal of NGF, cells undergo transcription-dependent cell death. The two factors that appeared to be most critical for converting PC1 2 cells into an NGF-dependent differentiated state were selecting an appropriate subline and then growing cells initially in a typical PC12 medium (RPMI containing 10\% horse and 5\% fetal calf serum) followed by subculturing cells and growing them in a medium more appropriate for primary cultures of neurons (DMEM/F1 2 containing $5 \%$ or $10 \%$ fetal calf serum or N2 serum-free components). As might be expected, there is no single point in time when the entire population of $\mathrm{PC} 12$ cells become dependent on NGF, but rather this occurs over several days. If cultures are grown in NGF for $5 \mathrm{~d}$ and then NGF removed, neurites degenerate but few if any cells die; however, starting around days 6-7 of NGF treatment, a small percentage of cells die when NGF is removed. The percentage of cells that die continues to increase over the next several days until by days
12-16, approximately $90 \%$ of the cells die following removal of NGF.

The sequence of events that occur following removal of NGF from PC12 cells are very similar to those occurring in sympathetic neurons following removal of NGF (Martin et al., 1988); however, events occur over a shorter time course in PC12 cells compared to sympathetic neurons. The progression of morphological events after removal of NGF from PC12 cells includes the following: (1) up until $10 \mathrm{hr}$ after removal of NGF, essentially all cells can be rescued if NGF or actinomycin D is added to the culture; (2) by 12-14 hr after removal of NGF, $50 \%$ of the cells are committed to die during the next $12 \mathrm{hr}$; (3) initial morphological signs of cell death at the light microscopic level are apparent 14-18 hr after removal of NGF and involve thinning and "bcading" of somc ncurites; (4) extensive fragmentation of neurites followed by active plasma membrane "blebbing" and degeneration of cell bodies occur between 20 and 36 hr.

An unexpected property of our system is that at approximately the same time cells become dependent on NGF for survival (days $6-10)$, spontaneous background death of cells $(1-3 \%$ in PC6-3 cells and up to $10 \%$ in PC2 cells) becomes apparent even in the continual presence of NGF. The nature of the background death in our cultures is unknown, and because it could complicate future biochemical and molecular studies, particular efforts were directed at establishing conditions to minimize background cell death. Once biochemical or molecular markers are available for transcription-dependent cell death it will be interesting to determine if the spontaneous background death is due to a "leaky" death program that is not totally inhibited by NGF, or if it represents a different typc of cell death. Addition of ATA does not block background cell death (Pittman, Wang, DiBenedetto, and Mills, unpublished observations); therefore, it does not appear to be the transcription-independent cell death that occurs in PC12 cells grown in serum-free medium in the absence of growth factors.

The PC12 system described in the present study in which cells undergo programmed cell death is different from that established by Greene's lab in which naive PC12 cells undergo transcription-independent cell death when shifted into serum-free medium in the absence of growth factors (Batistatou and Greene, 1991; Ruckenstein et al., 1991). A prominent feature of transcription-independent cell death in PC1 2 cells is activation of an endonuclease that results in laddering of DNA into 200 base pair nucleosomal fragments (Fig. 12; see also Batistatou and Greene, 1991). In agreement with previous studies (Batistatou and Greene, 1991; Ruckenstein et al., 1991), the endonuclease inhibitor ATA blocks transcription-independent cell death of our PC12 cells (Fig. 10). DNA laddering is present in a variety of cell types undergoing apoptotic cell death (for review, see Raff, 1992), and is postulated to be the cause of death in these cells (McConkey et al., 1989). Data in the present study are consistent with an endonuclease playing an important role in transcription-independent cell death of PC12 cells, but not in programmed (transcription-dependent) cell death. The only observation in our study inconsistent with those of Batistatou and Greene (1991) is that ATA does not have an appreciable effect on long-term survival of primary cultures of sympathetic neurons (Pittman, Wang, DiBenedetto, and Mills, unpublished observations), or differentiated PC12 cells (cells that undergo transcription-dependent death; Fig. 5). Under our tissue culture conditions (which are different from those used by Batistatou 
and Greene, 1991), ATA increases survival of both sympathetic neurons and differentiated PC12 cells $10-20 \%$ at early times following removal of NGF (14-30 hr); however, it has no effect on survival of cells after $36 \mathrm{hr}$. Because ATA affects a large number of cellular enzymes and systems (Bina-Stein and Tritton, 1976), and fragmentation of DNA would unlikely contribute to cell death of postmitotic neurons at these early times following loss of trophic support (see discussion below), it is difficult to attribute these modest effects on cell survival to alterations of a specific set of cellular processes.

Besides differences in the role of endonucleases in cell death, several other major differences exist between transcription-independent and -dependent cell death of PC12 cells. These include differences in the ability of $\mathrm{KCl}$, actinomycin $\mathrm{D}$, and cycloheximide to block cell death, and the death of PC6-4 cells in the transcription-dependent paradigm following removal of NGF, but their survival in the transcription-independent paradigm following culturing in serum-free medium in the absence of growth factors. Characterizing PC6-4 cells as well as variants that do not die in serum-free medium should be useful for identifying cellular mechanisms that block transcription-independent cell death. Understanding these mechanisms may help identify cellular events involved in transcription-independent cell death.

The molecules and/or events responsible for killing a cell are unknown, but it seems reasonable that degrading DNA into nucleosomal fragments would be lethal for an actively proliferating cell. However, for a postmitotic cell such as a neuron that can live for several days in the absence of RNA synthesis (Figs. 5, 13; see also Martin et al., 1988), fragmentation of its DNA may not be acutely lethal. Therefore, other mechanisms are likely to be primarily responsible for programmed cell death of neurons (such as aberrant channels or enzymes, or loss of mitochondrial function), while endonuclease activation and DNA fragmentation may act as a backup mechanism to ensure that the neuron eventually dies if the primary mechanisms fail. Therefore, DNA fragmentation may be a common feature of apoptotic cell death and, depending on whether a cell is actively proliferating or postmitotic, may be a primary cause of death or a backup system to ensure that death eventually occurs.

Although the primary goal of the present study was to establish a model for characterizing cellular and molecular events in programmed cell death, the system described here should also be useful for identifying events involved in the transition of cells from a proliferative neuroblast state to a differentiated postmitotic neuronal phenotype. A large number of genes and proteins have been identified that are present in highly differentiated cells; however, little is known about cellular changes involved in converting cells from a proliferative to a postmitotic state. Downregulation of cdc 2 and cyclin A have been correlated with the loss of proliferative capacity of neuronal precursors (Hayes et al., 1991), and increased DNA methylation and subsequent inactivation of genes is a property of many differentiated cells (Cedar, 1988; Bird, 1992). Having a homogeneous population of cells such as PC6-3 cells that is converted from an immortalized proliferative state to a differentiated nonproliferative state should be useful for identifying and characterizing events involved in this transition.

In summary, the availability of a large amount of tissue and a homogeneous population of cells should make PC6-3 cells a good model system for characterizing cellular, biochemical, and molecular events in programmed neuronal cell death. In addi- tion, these cells should be useful for investigating molecular events involved in the transition of cells from a proliferative to a postmitotic state. Because these cells are derived from a clonal line, further characterization is needed before it can be determined if PC6-3 cells will be a useful model system for investigating other properties of primary cultures of neurons and/or neurons in vivo.

\section{References}

Batistatou A, Greene L (1991) Aurintricarboxylic acid rescues PC12 cells and sympathetic neurons from cell death caused by nerve growth factor deprivation: correlation with suppression of endonuclease activity. J Ccll Biol 115:461-471.

Bina-Stein M, Tritton TR (1976) Aurintricarboxylic acid is a nonspecific enzyme inhibitor. Mol Pharmacol 12:191-193.

Bird A (1992) The essentials of DNA methylation. Cell 70:5-8.

Bottenstein JE, Skaper SD, Varon SS, Sato GH (1980) Selective survival of neurons from chick embryo sensory ganglionic dissociates utilizing serum-free supplemented medium. Exp Cell Res 125:183190.

Burton L, Wilson W, Shooter E (1978) Nerve growth factor in mouse saliva. J Biol Chem 253:7807-7812.

Cabaud PG, Wroblewski F (1958) Colorimetric measurement of lactic dehydrogenase activity of body fluids. Am J Clin Pathol 30:234-239.

Cedar H (1988) DNA methylation and gene activity. Cell 53:3-4.

Chang J, Martin D, Johnson E (1990) Interferon suppresses sympathetic neuronal cell death caused by nerve growth factor deprivation. J Neurochem 55:436-445.

Clarke P (1990) Developmental cell death: morphological diversity and multiple mechanisms. Anat Embryol (Berl) 181:195-213.

Cohen J, Duke R (1984) Glucocorticoid activation of a calcium-dependent endonuclease in thymocyte nuclei leads to cell death. J Immunol 132:38-42.

Davis R, Thomas M, Cameron J, John T, Scherer S, Padgett R (1980) Rapid DNA isolations for enzymatic and hybridization analysis. Methods Enzymol 65:404-411.

Duke RC, Cohen JJ (1986) IL-2 addiction: withdrawal of growth factor activates a suicide program in dependent $T$ cells. Lymphokine Res 5:289-299.

Edwards SN, Buckmaster AE, Tolkovsky AM (1991) The death programme in cultured sympathetic neurons can be suppressed at the posttranslational level by nerve growth factor, cyclic AMP, and depolarization. J Neurochem 57:2140-2143.

Ellis H, Horvitz H (1986) Genetic control of programmed cell death in the nematode $C$. elegans. Cell 44:817-829.

Ellis RE, Yuan J, Horvitz HR (1991) Mechanisms and functions of cell death. Annu Rev Cell Biol 7:663-698.

Greene L, Tischler A (1976) Establishment of a noradrenergic clonal line of rat adrenal pheochromocytoma cells which respond to nerve growth factor. Proc Natl Acad Sci USA 73:2424-2428.

Halegoua S, Armstrong RC, Kremer NE (1991) Dissecting the mode of action of a neuronal growth factor. Curr Top Microbiol Immunol 165:119-170.

Hansen M, Nielsen S, Berg K (1989) Re-examination and further development of a precise and rapid dye method for measuring cell growth/cell kill. J Immunol Methods 1 19:203-210.

Hayes T, Valtz N, McKay R (1991) Downregulation of CDC2 upon terminal differentiation. New Biol 3:259-269.

Hedgecock EM, Sulston JE, Thompson JN (1983) Mutations affecting programmed cell deaths in the nematode Caenorhabditis elegans. Science 220:1277-1279.

Hengartner M, Ellis R, Horvitz R (1992) Caenorhabditis elegans gene ced-9 protects cell from programmed cell death. Nature 356:494-499.

Hevelone J, Hartman PS (1988) An endonuclease from Caenorhabditis elegans: partial purification and characterization. Biochem Genet 26: $447-461$.

Horvitz HR, Ellis HM, Sternberg PW (1982) Programmed cell death in nematode development. Neurosci Comment 1:56-65.

Ivins JK, Pittman RN (1989) Growth cone-growth cone interactions in cultures of rat sympathetic neurons. Dev Biol 135:147-157.

Ivins JK, Raper JA, Pittman RN (1991) Intracellular calcium levels do not change during contact mediated collapse of chick DRG growth cone structure. J Neurosci 11:1597-1608. 
Koike T (1992) Molecular and cellular mechanism of neuronal degeneration caused by nerve growth factor deprivation approached through PC12 cell culture. Prog Neuropsychopharmacol Biol Psychiatry 16:95-106.

Koike T, Martin D, Johnson E (1989) Role of $\mathrm{Ca}^{2+}$ channels in the ability of membrane depolarization to prevent neuronal death induced by trophic-factor deprivation: evidence that levels of internal $\mathrm{Ca}^{2+}$ determine nerve growth factor dependence of sympathetic ganglion cells. Proc Natl Acad Sci USA 86:6421-6425.

Levi A (1991) The mechanism of action of nerve growth factor. Annu Rev Neurosci 31:205-228.

Lockshin RA (1969) Programmed cell death. Activation of lysis of a mechanism involving the synthesis of protein. J Insect Physiol 15: 1505-1514.

Martin D, Schmidt R, DiStcfano P, Lowry O, Carter J, Johnson E (1988) Inhibitors of protein synthesis and RNA synthesis prevent neuronal death caused by nerve growth factor deprivation. J Cell Biol 106:829-844.

Martin D, Wallace T, Johnson E (1990) Cytosine arabinoside kills postmitotic neurons in a fashion resembling trophic factor deprivation: evidence that a deoxycytidine-dependent process may be required for nerve growth factor signal transduction. J Neurosci 10 : 184-193.

McConkey D, Hartzell P, Nicotera P, Orrenius S (1989) Calciumactivated DNA fragmentation kills immature thymocytes. FASEB J 3:1843-1849.

McConkey DJ, Hartzell P, Chow SC, Orrenius S, Jondal M (1990) Interleukin 1 inhibits $\mathrm{T}$ cell receptor-mediated apoptosis in immature thymocytes. J Biol Chem 265:3009-301 1.

Melloni E, Pointremoli S (1989) The calpains. Trends Neurosci 12: 438-444.

Mosmann T (1983) Rapid colorimetric assay for cellular growth and survival: application to proliferation and cytotoxicity assays. J Immunol Methods 65:55-63.

Oppenheim R (1991) Cell death during development of the nervous system. 14:453-501.

Oppenheim R, Prevette D, Tytell M, Homma S (1990) Naturally occurring and induced neuronal death in the chick embryo in vivo requires protein and RNA synthesis: evidence for the role of cell death genes. Dev Biol 138:104-113.

Pittman RN, Ivins JK, Buettner HM (1989) Neuronal plasminogen activators: cell surface binding sites and involvement in neurite outgrowth. J Neurosci 9:4269-4286.

Raff M (1992) Social controls on cell survival and cell death. Nature 356:397-400

Rukenstein A, Rydel R, Greene L (1991) Multiple agents rescue PC12 cells from serum-free cell death by translation- and transcriptionindependent mechanisms. J Neurosci 11:2552-2563.

Schwartz L, Myer A, Kosz L, Engelstein M, Maier C (1990a) Activation of polyubiquitin gene expression during developmentally programmed cell death. Neuron 5:411-419.

Schwartz LM, Kosz L, Kay BK (1990b) Gene activation is required for developmentally programmed cell death. Proc Natl Acad Sci USA 87:6594-6598.

Schwartzman R, Cidlowski J (1991) Internucleosomal deoxyribonucleic acid cleavage activity in apoptotic thymocytes: detection and endocrine regulation. Endocrinology 128:1190-1197.

Scott SA, Davies AM (1990) Inhibition of protein synthesis prevents cell death in sensory and parasympathetic neurons deprived of neurotrophic factor in vitro. J Neurobiol 21:630-638.

Shi Y, Sahai B, Green D (1989) Cyclosporin A inhibits activationinduced cell death in T-cell hybridomas and thymocytes. Nature 339: 625-626.

Sulston JE (1976) Post-embryonic development in the ventral cord of Caenorhabditis elegans. Philos Trans R Soc Lond [Biol] 275:287298.

Sulston JE, Horvitz HR (1977) Post-embryonic cell lineages of the nematode Caenorhabditis elegans. Dev Biol 82:41-55.

Tata JR (1966) Requirement for RNA and protein synthesis for induced regression of tadpole tail in organ culture. Dev Biol 13:77-88.

Wallace T, Johnson E (1989) Cytosine arabinoside kills postmitotic neurons: evidence that deoxycytidine may have a role in neuronal survival that is independent of DNA synthesis. J Neurosci 9:115124

Williams GT, Smith CA, Spooncer E, Dexter TM, Taylor DR (1990) Haemopoietic colony stimulating factors promote cell survival by suppressing apoptosis. Nature 343:76-78.

Wyllie A, Morris R, Smith A, Dunlop D (1984) Chromatin cleavage in apoptosis: association with condensed chromatin morphology and dependence on macromolecular synthesis. J Pathol 142:67-77.

Yuan J, Horvitz H (1990) The Caenorhabditis elegans genes ced-3 and ced -4 act cell autonomously to cause programmed cell death. Dev Biol 138:33-41. 